\title{
AIKUISKASVATUKSEN KEHITYS VENÄJÄLLÄ
}

\author{
Semen G. Veršlovski
}

\begin{abstract}
A ikuiskasvatuksen historia Venäjällä alkoi 860- ja 70-luvuilla, jolloin perustettiin ensimmäiset sunnuntaikoulut. Opetus rajoittui perustaitoihin (lukemiseen, kirjoittamiseen ja laskentaan). Opiskelu oli ilmaista ja opettajien työ vapaaehtoista ja korvauksetonta. 1880-luvulla sunnuntaikoulujen rinnalle syntyi työläisten iltakursseja.
\end{abstract}

$\mathrm{V}$ uoden 1917 Lokakuun vallankumouksen jälkeen näiden järjestelmien tilalle tulivat lukutaidottomuuden hävittämisasemat ja muut aikuisille tarkoitetut kasvatusjärjestelmät, joita olivat esimerkiksi 1920-luvun puoleenväliin asti toimineet työläistiedekunnat. Niissä aikuiset saattoivat saada yleisen keskiasteen koulutuksen. $\mathrm{Ne}$ olivat osa yhtenäistä valtiollista kasvatusjärjestelmää, ja ne pyrkivät ratkaisemaan tärkeitä yhteiskunnallis-kulttuurisia tehtäviä, kuten lukutaidottomuuden hävittämistä ja älymystön sosiaalisen rakenteen laajentamista.

Myös koulujen ulkopuolinen aikuisopetus syntyi ennen vallankumousta. Sen muodosti kansalaisjärjestöjen ja yksityishenkilöiden valistustyö, joka oli suunnattu aikuisväestön kasvatuksellisiin tarpeisiin. Termi "koulujen ulkopuolinen opetus" muuttui vähitellen "poliittis- tai kulttuuriskasvatukselliseksi työksi”. Valistustyö alistettiin 1940-luvun lopulla Yleisliittolaisen poliittisen ja tieteellisen tiedon levittämisjärjestön alle (vuodesta 1962 Znanie-seura, ”TIETO-seura"). Kansanyliopistot olivat yksi suosituimmista aikuiskasvatusmuodoista. 1980-luvulla kansankorkeakouluja oli jo noin 60000 ja niissä opiskeli yli 20 miljoonaa ihmistä. Samanaikaisesti toimi iltakouluja, jotka jakoivat keskiasteen koulutusta. 1980-luvun lopulla näissä opiskeli noin 500000 ihmistä.

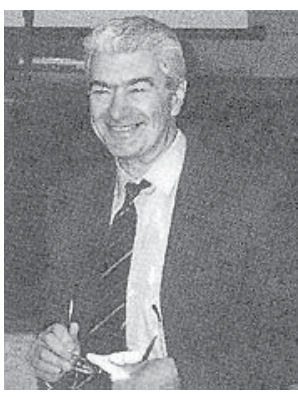

Aikuiskasvatusjärjestelmän vakiinnuttamisessa, sen tarkoituksen pohtimisessa ja opetusjärjestelmien kehittämisessä merkittävää työtä tekivät K. D. Uðinskij, P.F. Kapterçv, V.P. Vahterov, E.N. Medynskij ja muut merkittävät pedagogit. Myöhemmin aikuiskasvatusta kehittivät aktiivisesti A.V. Darinskij, V.G. Onuškin ja heidän työtoverinsa. Kokonaisuudessaan voidaan sanoa, että neuvostoaikana vakiintui valtiollis-yhteiskunnallinen aikuiskasvatusjärjestelmä, jossa valtiolliset järjestelmät kuitenkin aktiivisesti syrjäyttivät omaaloitteiset. Aikuiskasvatus oli selkeästi ideologisesti suuntautunut. Sillä oli erityisesti sopeuttava ja korvaava luonne, tavoitteena yksilön sopeuttaminen yhteiskuntaan.

1980-luvun lopulla alkanut suuri murros sosiaalis-ekonomisissa suhteissa ja yhteiskunnan kaikkien piirien uudelleenjärjestäytyminen johtivat kaikilla tasoilla (valtakunnallisella, alueellisella ja kunnallisella) kasvatuksen valtiontuen huomattavaan vähentämiseen. Lopulta koko järjestelmä lakkasi toimimasta ja sen raunioilta nousi täysin erilainen järjestelmä. Yhtenä sen erikoisuutena oli kasvatuspalveluiden kaupallistuminen. Toisaalta tämä saattoi kannustaa opettajien työtä ja kehittää opetuksen materiaalista ja teknistä tasoa, mutta toisaalta kaupallistumisella oli huomattavan negatiivisia seurauksia: kaikki väestöryhmät eivät kykene ostamaan kalliita opiskelupalveluja, eikä korkea hinta takaa adekvaattista tasoa. ${ }^{1}$ Valtion niukka taloudellinen tuki sellaisilla kansantalouden aloilla, kuten terveydenhoidossa ja valistustyössä, laadun varmistamisessa ja kehittämistyössä heijastuvat lääkäreiden ja opettajien osaamiseen.

Samalla ilman valtiontukea toimivasta aloitekyvystä syntyi ja aktiivisesti kehittyi kansalaispoh- 
jalla toimiva aikuiskasvatusjärjestelmä. Vaihtoehtoisista kasvatusjärjestelmistä tuli valtiollisiin nähden liikkuvampia joustavuuden, haaroittuneisuuden ja vähemmän jähmettyneiden ohjelmien ansiosta. Näin valtiollisen ja kaupallisen sektorin lisäksi on kehittynyt omaperäinen aikuiskasvatuksen kolmas sektori. Tällainen aloitekyky on avuksi kehitettäessä kansalaisyhteiskuntaa ja kansalaisten vastuuta yhteiskunnan tilasta. Voidaan olettaa, että tällaisen aloitekyvyn merkitys kansalaisyhteiskunnan synnyttämisessä Venäjälle on vahvistumassa.

\section{Yhteiskunnan muutos ja kouluttautumisen uudet tarpeet}

O osiaalisten muutosten kautena aikuiskasvatukSen sisältö, rakenteet ja suuntautuminen määräytyvät lähinnä itse käyttäjien tarpeiden mukaan. Venäläisen yhteiskunnan kriisi näkyy suoraan heidän odotuksissaan ja arvomaailmassaan. Sosiaalisten muutosten aiheuttamiin aikuisten erityispiirteisiin voidaan liittää:

- materiaalisen tason eriytyminen ja sosiaalisesti puolustuskyvyttömien ihmisryhmien kasvu;

- väestön korkea sosiaalispsyykkinen jännitys ja väsyminen;

- moraalinen harhautuminen;

- yksilön itsekeskeisten arvojen kasvaminen, joka kohdistuu lyhyen aikavälin selviytymiseen;

- moraalisen tietoisuuden matala taso, usko voimankäytön oikeutukseen ongelmien ratkaisemisessa;

- sosiaalispsyykkinen lukutaidottomuus, kykenemättömyys kompromissien tekemiseen.

Nämä erityispiirteet määrittävät aikuisten suhtautumista eri elämänalat kattavaan tietoon. Kyselyin on osoitettu aikuisten kokevan tarvetta tietoihin, jotka ovat välttämättömiä fyysisen terveyden säilyttämiseksi ( $73 \%$ vastaajista), kanssakäymistaitoihin (64\%) ja ammatillisen osaamisen kohottamiseksi (toisen ammattitaidon hankkiminen varalle, uudet teknologiat, vieraat kielet yms. 61\%). Nämä tarpeet osoittavat aikuis- ten käyttäytymistä kasvatusmarkkinoilla. Ensi sijassa ihmiset kiinnostuvat mahdollisuuksiltaan ja tavoitteiltaan vaihtelevista kielikursseista, jotka laajentavat heidän ammatillisia ja sosiaalisia valmiuksiaan. Toisella sijalla ovat yrittäjyysohjelmat (johtaminen, markkinointi, tietotekniikka, kirjanpito yms.). Kolmannella sijalla ovat "teolliset" alat, palveluammatit jne. Sen jälkeen tulevat ei-professionaaliset lääketieteelliset kurssit sekä kodin- ja puutarhanhoito.

Aikuisten suuntautuminen käytännöllisille koulutusaloille on täysin ymmärrettävää. Aikuinen opettelee sellaista, mikä auttaa jokapäiväisissä vaikeuksissa. "Opiskeluohjelma" lähtee päivittäisistä ongelmista, siksi opiskelulla ei ole itsetarkoituksellista arvoa. Kun käytännön tarve on tyydytetty, katoaa myös tarve opiskella. ${ }^{2}$ Jos koulutustarjonnassa seurataan vain lyhytkestoisia tarpeita, jatkuva oppiminen ja sen persoonallisuutta kasvattava potentiaali kyseenalaistuu. Tätä osoittavat arviot, joita aikuiset ovat antaneet omasta asemastaan oppimisympäristössä:

- Jatkuva oman horisontin laajentaminen $30 \%$ vastanneista

- Opiskelu välttämättömästä tarpeesta $50 \%$

- Ajatus "oppimisen aika ei vielä ole ohi" 20 prosenttia.

Sanotun pohjalta voidaan tehdä seuraavia johtopäätöksiä:

- Viime vuosina väestölle on ollut tarjolla laaja valikoima kursseja ja ohjelmia, joilla voi tyydyttää erilaisia oppimistarpeita;

- Monien koulutuspalvelujen hinta on aikuisille todellinen kynnys; lisäksi näiden palvelujen hinta ei välttämättä takaa laatua;

- On syntynyt monipuolinen kasvatuksen kolmas sektori, joka on myös virike kohti kansalaisyhteiskuntaa;

- Kriisiyhteiskunnassa ajankohtaistuu sangen käytännöllinen opiskelutarve. Ja kun tarve on tyydytetty, poistuu myös välttämättömyys opiskelun jatkamiseen, niin muodollisella kuin non-formaalisellakin tasolla.

Katsotaan seuraavaksi, mihin suuntiin aikuiskasvatus pääpiirteissään kehittyy. 


\section{AIKUISKASVATUKSEN PERUSSUUNTIENANALYYSI}

$\mathrm{V}_{\mathrm{i}}$ enäjän aikuiskasvatuksesta voidaan asiantunija-analyysin perusteella erottaa seuraavia suuntauksia, joille on kertynyt arvokasta kokemusta.

1 Aikuisten ammatillinen oppiminen. Tämän ryhmän alla on kursseja niille, joilla ei ole ammatillista koulutusta, ammatillista kasvatusta niille, jotka ovat saaneet vain alimman tason ammattikoulutusta. Siihen kuuluvat myös osaamisen kartuttaminen erikoisinstituuteissa ja välittömästi sen jälkeen yrityksissä, asiantuntijoiden harjoittelut eturivin yrityksissä ja ulkomailla, kurssit työttömien ammatilliseksi orientoimiseksi ja psykologiseksi tukemiseksi ja toisen korkeakoulututkinnon hankkiminen.

Pääasiassa ammatillisen aikuiskoulutuksen yksiköt ovat ei-valtiollisia (kaupallisia ja ei-kaupallisia), erilaisten valtiollisten ministeriöiden ja hallinnonalojen laitoksia tai kunnallisia laitoksia. Myös yritykset kuuluvat tähän ryhmään aikuiskasvatuksen ja tuotannon tiiviin integroitumisprosessin vuoksi.

Kotimaisen talouden kriisitila on johtanut ammatillisen aikuiskasvatuksen rakenteen ja sisällön huomattavaan muuttumiseen, sillä teollisten investointien vähentyessä myös inhimilliseen pääomaan investoiminen on jyrkästi laskenut. Kysynnän väheneminen näkyy tarjottavien koulutuspalveluiden määrässä ja laadussa. Toisaalta palvelualoilla osaavien johtajien ja asiantuntijoiden tarve on jyrkästi kasvanut. Ajan kysyntään vastaavat kehittyvät johtamis-, kirjanpito-, turvallisuus- yms. alojen koulutus- ja jatkokoulutusohjelmat. Työaloilla tulkitaan uudelleen osaamiskyvyn käsitettä, johon liitetään ei vain ammatillis-teknisten tietojen ja kokemuksen hallinta, vaan myös sosiaaliset taidot yhteydessä pysyvään arvomaailmaan. Tämä tulkinta on aktivoinut sellaisten ongelmien analyysin kuin nuorten asiantuntijoiden ammatillinen sopeuttaminen sosiokulttuurilliseen ympäristöön, työyhteisön konfliktien ratkaisu, työntekijöiden kiintymyksen kasvattaminen yritykseen, yksilön työ- potentiaaliin vaikuttavan terveyden säilyttäminen jne. Toisaalta nämäkään ohjelmat eivät erotu kilpailukykyisyydellään. Palvelujen tuonnin [import] määrä on suuri varsinkin kaikkein maksukykyisimmillä kysynnän aloilla - johtajien ja talousasiantuntijoiden jatkokoulutuksessa.

Voidaan olettaa, että tuotannon kasvun myötä myös valtiollisten ja yhteiskunnallisten laitosten huomio niin kansallisella kuin alueellisellakin tasolla kiinnittyy ammatillisen aikuiskasvatuksen ongelmiin. Samalla voidaan olettaa, että kehittyneille maille ominaisesta työn ja jatkokoulutuksen integroinnista tulee ominainen tendenssi myös venäläiselle tuotannolle.

\section{2} Koulutus invalidien sosiaalisen sopeuttamisen keinona. Viime aikoihin asti invalidien koulutus ei ollut valtiollisella tasolla itsenäinen aikuiskoulutuksen ala. Nykyään sitä pidetään yhtenä päävälineenä invalidien sosiaalisessa rehabilitoinnissa ja siksi se siirtyi valtiollisen avun piiriin, jota annetaan eri tasoilla:

- ammatillista koulutusta antavat erikoiskoulut;

- ala- ja keskiasteen erikoiskoulutus, johon kuuluvat tekniset sisäoppilaitokset ja ulkooppilaiden opistot;

- korkeakouluopetuksessa näkö-, kuulo- yms. vammaisille.

Samalla on aktivoitunut monien epävirallisten järjestöjen, yhdistysten ja liittojen toiminta, joiden tarkoituksena on herättää invalideissa kiinnostusta kirjallisuuteen, taiteeseen ja käsitöihin (Pietarissa Nadezhda- eli "Toivo"-ohjelma, Karjalassa Blagodat eli "Siunaus" yms.) Esimerkiksi Karjalan radiolla on erityinen invalideille suunnattu ohjelmasarja, joka käsittelee laaja-alaisesti oikeudellisia ja lääketieteellisiä ongelmia. Moni asia riippuu kuitenkin järjestöjen jäsenten innostuksesta.

Viime aikoina on ollut havaittavissa pyrkimys vahvistaa ja perustaa invalidien omia nuorisojärjestöjä. Näiden järjestöjen perustoimintana on järjestää koulutusta yksittäisille invalideille kotiolosuhteissa, järjestää koulutusta erityisryhmille mahdollisilla aloilla sekä vapaaehtoistyö yms. ${ }^{3}$ 
3 Naisten koulutus. Neuvostoliiton jälkeisen Venäjän avoimuus on pakottanut epäilemään aikaisemmin julistettua elitististä politiikkaa ja on näyttänyt yhteiskunnan käytäntöjen avoimen seksismin. Teoreettisten ja empiiristen tutkimusten analyysin pohjalta voidaan erottaa seuraavia tekijöitä, jotka lisäävät naisten epätasa-arvoisuutta valmistumisen jälkeisessä koulutustilanteessa:

- Naisten kahtalainen rooli: kiinnittyminen samalla ammatilliseen ympäristöön sekä kodinja lastenhoitoon

- Ennakkoluulot ja stereotypiat, jotka naisten tyypillisistä ominaisuuksista on yleisessä tietoisuudessa

- Naisten pitäminen reservinä, lisätyövoimana, jonka tarve vähenee taloudellisen laman aikaan.

Viime aikoina on huomattavasti aktivoitunut koulutus, joka tähtää selkeän ja näkymättömän seksismin seurausten voittamiseen. Naisille suunnattujen koulutuslaitosten kokemuksista voidaan tehdä seuraavia johtopäätöksiä:

Ensimmäinen ryhmä - lisäkoulusta antavat laitokset, jotka kouluttavat markkinoiden vaatimia ammattiryhmiä (kirjanpitäjiä, kassanhoitajia, notaareja yms.) Näissä laitoksissa on kursseja, jotka on suunnattu erityisesti naisille (esimerkiksi autokouluja)

Toinen ryhmä - naisia nykyiseen sosiaalis-ekonomiseen tilaan integroivat laitokset (Pietarissa Kansainvälinen zhensina i upravlenie, "Nainen ja johto"-Instituutti).

Kolmas ryhmä - naisyhdistykset, jotka piirissään käsittelevät yksityisen ja yhteiskunnallisen tason ongelmia (Ivanovossa Delovaâ zhensina eli "Liikenainen", Pietarissa "Vasilisa" yms.)

Viime aikoina tutkijoiden kiinnostus gendertutkimukseen on huomattavasti kasvanut. Monissa yliopistoissa on aiheeseen liittyviä erikoiskursseja ("Naiset keskiajan Venäjällä", "Feminismi ja yhteiskunta 1900-luvun taitteessa" (Samara, Ivanovo yms.)

$\Lambda$ Perhekasvatus. Pitkään perhekasvatus perustui vanhempien psykologis-pedagogiseen valistukseen, jota pitivät koulujen pedagogiset kollektiivit perinteisen kaavan mukaan (luennot, lapsen edistymisen analysointi jne.) Nykyään vanhempien kasvatus on saanut huomattavasti demokraattisemman ja entistä vähemmän muodollisen luonteen. Erityisesti suosiota ovat saaneet "pyöreät pöydät", joissa käsitellään laaja-alaisia ongelmia ("Vanhempien oikeudet ja velvollisuudet", "Vanhempien rooli koulun johdossa", "Isän rooli lapsen kasvatuksessa" yms.)

Perhekasvatuksen tärkeäksi osaksi ovat tulleet perheen sisäiset kysymykset (perhekonfliktologia). On syntynyt psykologisen avun keskuksia, ongelmapuhelimia, vanhempainjärjestöjä (Pietari, Tambov, Brjansk ja muualla).

Kolmannen ikäluokan koulutus. Itsenäisenä $\mathcal{~ t a ̈ m a ̈ ~ a l a ~ o n ~ s y n t y n y t ~ v a s t a ~ v i i m e ~ v u o s i n a . ~ S e n ~}$ syntyminen liittyy välittömästi väestön vanhenemiseen. Nykyisin Venäjällä on 34 miljoonaa eläkeläistä. Esimerkiksi Pietarin 4,7 miljoonasta asukkaasta 1,3 miljoonaa on eläkeläisiä. Toisaalta sekä kotimaiset että ulkomaiset tutkimukset ovat osoittaneet koulutuksen toimivan sosiaaliturvana vanhuksille. ${ }^{4}$

Syntynyt kokemus osoittaa tämän ikäryhmän oppimisen erikoispiirteitä:

1. Erona muista opetusjärjestelmistä, jotka sopeutuvat ja mukautuvat sosiaalisissa muutoksissa, näiden järjestelmien elinvoima vähenee huonoissa olosuhteissa jyrkästi. Koulutuksen sisällössä korostuvat selviytyminen ja sosiaaliturva.

2. Luodaan yhteys instituutteihin, jotka toteuttavat sosiaaliturvaa ja -huoltoa sekä lääketieteellistä seurantaa.

3. Vähäinen taloudellinen arvostus ja siksi vähäinen valtionapu sekä käytännössä puuttuva kaupallisten tahojen tuki johtavat siihen, että ikääntyneet ihmiset usein pyrkivät omatoimiseen kulttuurilliskasvatuksellisten ongelmien ratkaisuun perustamalla vapaaehtoisjärjestöjä, kerhoja, liittoja yms.

Kolmannen ikäpolven koulutus ja itsekoulutus ovat vasta alussa. Vain 1,5 prosenttia kolmannen ikäluokan ihmisistä tyydyttää opiskelutarpeensa järjestäytyneiden oppimisjärjestelmien kautta.

Yleisenä, ikääntyvää väestöä kiinnostavana suun- 
tauksena on erilaisten sosiaalisten järjestöjen kasvu. Voidaan erottaa erityyppisiä järjestöjä, jotka auttavat ikääntyvää väestöä suoraan tai välillisesti kouluttautumisessa.

Yksi järjestötyyppi yhdistää ihmisiä jonkin yhteiskunnallisen ominaisuuden mukaan ("Repressioiden syyttömien uhrien järjestö", "Piiritetyn Leningradin lasten järjestö” yms.). Tällaiset järjestöt auttavat jäseniään liittymään monenlaiseen kulttuurilliskasvatukselliseen toimintaan.

Toinen järjestötyyppi on suuntautunut suoraan eläkeläisten sosiaaliturvaan. Nämä järjestöt toimivat hyväntekeväisyyspohjalla. Vaikka nämä järjestöt pyrkivät ensi sijassa sosiaaliseen huoltoon ja vanhenevan ihmisluokan ensisijaisten tarpeiden täyttämiseen, ne luovat myös kommunikatiivisia suhteita, joilla on suuressa määrin informatiiviskasvatuksellinen luonne.

Kolmas järjestötyyppi tällaisista järjestöistä kattaa erilaisen ylimääräisen opetustoiminnan (kurssit, kerhot, luennot yms.). Yksi toiminnan muoto on ns. kansankoulut. Yksi niistä - Ylin kansankoulu - avattiin vuonna 1998 alueellisen kansalaisjärjestön Dom Evrope v Sankt-Peterburge, "Pietarin Eurooppa-talon" toimesta. Sen tarkoituksena on tyydyttää erilaiset aikuisväestön yksilölliset oppimistarpeet, luoda miellyttävä ympäristö kuulijoiden kanssakäymiseen ja auttaa näiden yhteisen kulttuurin kehittymisessä.

Valitettavasti Venäjän nykyinen järjestelmä ei piittaa yhdestä kaikkein tärkeimmistä kolmannen ikäluokan ongelmista, terveyden säilyttämisestä. Sen tilalla on omatoiminen tiedonhankinta, lähteinä halpa kirjallisuus, tiedotusvälineet ja kansanparantajien ilmaiset massanäytännöt.

\section{Kansallinen ja kansallishenkinen kasvatustyö mo-} monta syytä. Ensinnäkin ihmisten kiinnostus kansalliseen perintöön on kasvanut Neuvostoliiton hajoamisen jälkeen. Voidaan puhua ennakkotapauksettomasta historiallisiin tapahtumiin ja vaiheisiin kohdistuvasta kansallistunteen ryöpystä. Kaikki, mikä oli ennen tukahdutettu, vaihdettu luokkanäkökulmaan tai metaetnisyyden eli ylikansallisuuden ylistämiseen, on nyt noussut esille.
Kiinnostus kansallisiin ja kulttuurillisiin juuriin on kärjistynyt monikansallisissa suurkaupungeissa, joissa luonnollisena tendenssinä on assimilaatio. Toisaalta selkeästi kansallinen muuttoliike on lisääntynyt. Tilastotietojen mukaan esimerkiksi vuonna 1996 Pietarin väkiluvussa muuttoliike näkyi 3,4 tuhannen asukkaan ja koko alueella 14000 asukkaan kasvuna. ${ }^{5}$ Tämä on johtanut ongelmiin uuden väestön sopeuttamisessa kaupunkikulttuuriin ja monien osalta venäjän kielen opettamisessa. Näitä ongelmia ratkaisevat kansallis-kulttuurilliset keskukset ( TARGIM, joka yhdistää Ingušetiasta tulleita, ÈIŠMA - tataarien ja baškiirien järjestö yms.) sekä sunnuntaikoulut. Nämä kasvatusjärjestöt auttavat kansallistietoisuuden herättämisessä ja kehittämisessä, tekevät huomattavaa valistustyötä ja vahvistavat ystävällisiä suhteita muihin pohjoisen pääkaupungin kansoihin. Samalla kuitenkin yhteiskunnan tuki kansalliseen koulutukseen on jäänyt tarpeista jälkeen.

Vaikka aikuiskasvatuksen perusmuodot on kuvattu tässä sangen lyhyesti, voi niitä kuitenkin käyttää pohjana seuraaviin johtopäätöksiin:

1 Koulutusjärjestelmä muovautuu aikuisväestön erilaisuudesta: ammatillisen ja asemasta johtuvan erilaisuuden, ikä- ja sukupuolierojen mukaan. Samalla koko järjestelmästä tulee entistä joustavampi. Sen mahdollisuudet yksittäisten ihmisryhmien, kuten vanhusten, invalidien tai riskiryhmien sosiaaliturvassa kasvavat.

2 Kansalaisjärjestöjen merkitys kasvaa ja kansalaisjärjestöt tekevät arvokkaita aloitteita suurten ihmisryhmien tavoittamiseksi (pedagogit, sponsorit, keskus- ja paikallishallinto, radio ja televisio) aikuiskasvatuksen ongelmien ratkaisemisessa. Yksi tällaisista aloitteista on projekti "Aikuisoppimisen viikko 2001" siirtyvässä kansainvälisessä Nizhnij Novgorodin - Astrahanin instituutissa. Viikon järjestäjä on Znanie-järjestö "Euroopan talo Pietarissa" Venäjän osastosta. Viikon tarkoituksena on saavuttaa aikuiskasvatukselle tunnustus välttämättömänä oppimisyhteiskunnan ehtona, murtaa rajoittunut, yksinomaan koululaitoksiin perustuva näkemys koulutuksesta sekä yhdistää alueiden voimat tehokkaampaan aikuis- 
kasvatuskentän ongelmien ratkaisemiseen. On aihetta olettaa, että ajan myötä aikuiskasvatuksen kysymykset menettävät kapean hallinnonalaisen luonteensa ja muuttuvat suureksi yhteiskunnalliseksi ongelmaksi.

3 Formaalin ja non-formaalin aikuiskoulutuksen integraatio on selvästi havaittava suuntaus, mikä auttaa laajentamaan oppijoiden kenttää. Eräiden arvioiden mukaan erilainen kasvatustyö kattaa nykyään noin kolmanneksen Venäjän väestöstä. Tätä lukua ei voida verrata neuvostoaikaiseen, mutta verrattuna muutamaa vuotta aikaisempaan se kertoo vääjäämättömästä aikuisoppijoiden määrän kasvusta.

\section{AIKUISKASVATUSJÄRJESTELMIEN VERTAILEVAANALYYSI VENÄJÄ- LÄNSI-EUROOPPA}

$\mathrm{V}$ enäjän aikuiskasvatusjärjestelmän suuntausten analyysi toimii pohjana sen vertailulle eurooppalaisiin järjestelmiin.

\section{Valtiollisen politiikan tasolla:}

Eurooppalaisen järjestelmän mukaan aikuiskasvatus nauttii lain suojaa. Venäjällä tällaisia lakeja ei ole vielä säädetty. Valtiollinen tuki koskee vain ammatillista koulutusta ja tiettyjen väestöryhmien (työttömien, invalidien) jatkokoulutusta. Myöskään paikallista budjeteista ei liikene rahoitusta aikuiskasvatukselle.

\section{Opetusjärjestelmän puitteissa:}

Euroopassa hyvin suosittuja opiskelumuotoja ovat kansalaisopistot ja kansanopistot. Toistaiseksi Venäjällä vastaavaa demokraattista ja kaikkien saavutettavissa olevaa opiskelujärjestelmää ei ole laajassa mittakaavassa. Tyypillinen aikuiskoulutuksen muoto ovat lyhytkestoiset kurssit.

\section{Opetusmetodien tasolla:}

Venäjän aikuiskasvatusjärjestelmä ottaa vasta ensiaskeliaan eurooppalaisten menetelmien soveltamisessa (ryhmätyö tai etäopiskelu). Uudet metodit leviävät lähinnä ei-valtiollisten opetuslaitosten kautta.

Suurien yhteiskunnallisten kysymysten lisäksi eroihin vaikuttaa myös Venäjän aikuisopettajien riittämätön valmennus.

\section{ONGELMAT UUDEN VUOSISADAN KYNNYKSELLÄ}

Voidaan erottaa tärkeimmät ongelmat, joiden ratkaisusta ihmisyksilön ja yhteiskunnan kehitys paljolti riippuvat.

$\mathrm{K}$ un opetus keskittyy käytännön asioihin, kuten ammatillisiin asioihin ja yksityiselämään, syrjäytyvät koulutuksen sisältöinä henkiset kriisit, jotka ovat seurausta elämänarvojen väistämättömästä murroksesta aikakauden vaihtuessa. Ihmisten hämmennys estää heitä löytämästä moraalista tukipistettä, kehittämästä käyttäytymiselleen pohjaa vastavoimaksi elämän olosuhteille. Sen sijaan tapahtumat heijastuvat reaktioina, joiden perustana on epäasiallinen, väärä tai riittämätön informaatio tai ihmisten taipumus etsiä yksinkertaisia vastauksia monimutkaisiin ongelmiin. Näin syntyy pyrkimys suppeita piirejä koskeviin harrastuksiin, kiinnostus okkultistiseen kirjallisuuteen ja uskonnollisiin lahkoihin.

Tuskin voidaan olettaa, että "puhtaasti" moraalis-psykologinen kasvatus voisi saavuttaa suurtakaan osaa väestöstä. Pikemminkin pitäisi puhua minkä tahansa opetuksen filosofisen ja moraalispsykologisen kytkennän vahvistamisesta. Pitäisi siis pyrkiä sellaiseen ongelmanasetteluun, mikä johtaisi aikuiset ulos vain selviytymisen ja elämän kustantamisen kysymyksistä. Yksi keskeisistä tällaisen opetuksen ideoista on ihmiselämän itseisarvo ja mahdollisuus ihmisonneen mistä tahansa sattuneista historiallisista olosuhteista huolimatta. Tällaisen "korkeamman" tehtävän ratkaiseminen ei merkitse vain sopeuttavan ja korvaavan (adaptiivis-kompensatorisen) tehtävän täyttymistä, vaan se merkitsee myös aktiivista vaikuttamista yksilön kasvuun ja elämänarvojen rikastamista.

Toisaalta myös avoin keskustelu yksityiselämän ongelmista, ihmissuhteista ja eletyn elämän arvoista on välttämätöntä.

$\mathrm{O}$ n myös kasvanut tarve kasvattaa kansalaisten oikeuskulttuuria nykyvenäläisessä yhteiskunnassa eli tiedottaa perusoikeuksista ja yhteiskunnan oikeuspalveluista. 
1 Näiden tehtävien ratkaisu edellyttää niin formaalin, non-formaalin kuin informaalinkin kasvatuksen voimien yhdistämistä. Kokonaisuudessaan tämän ongelman voisi nimetä välttämättömyydeksiyhdistääjatkokoulutusja muntopetusmuodotyleiskulttuurillisten muotojen kanssaehjän ihmiselämänehtona.

2 Aikuiskasvatuksen laadullisen kehityksen ohella kasvatuksen kentän tulisi laajeta myös leveyssuunnassa ja saavuttaa uusia ihmisryhmiä. Tämä tarkoittaa erityisesti marginaalisia ihmisryhmiä, kuten vankeja. Nämä ihmiset tarvitsevat osakseen suurta yhteiskunnan huomiota. Yksi tällainen on kehittää kaikinpuolisia opetusjärjestelmiä tällaisten ihmisryhmien tarpeisiin soveltuviksi.

3 Koulutuspalvelujen laaja leviäminen aset$\mathcal{~ t a a ~ k y s y m y k s e n ~ n i i d e n ~ l a a d u s t a . ~ E l l e i ~ y h t e i s - ~}$ kunta ryhdy toimenpiteisiin kuluttajalle tarjottujen kurssien, seminaarien ja koulujen asiantuntijatarkastusten toteuttamiseksi, se törmää välttämättä kaikenlaiseen harrastajamaisuuteenja kyvyttömyyteen, joita oikeutetusti nimitetään nykyyhteiskunnan vitsauksiksi.

4 Erotuksena moniin muihin maihin ei Venäjän aikuiskasvatuksella ole normatiivis-oikeudellista pohjaa. Aikuiskasvatuksen käsite puuttuu Venäjän federaation laeista. Vaikka kansalliseen opetusdoktriiniin on kirjattu tavoitteeksi "jatkuva elinikäinen oppiminen", ei aikuiskasvatuksen paikkaa ja roolia ole tässä prosessissa määritelty. Doktriini keskittyy vain kouluopetuksen ongelmiin. Uusissa projekteissa kasvatuksen merkitystä Venäjän modernisoimiseksi on lisätty, mutta aikuiskasvatuksen käsite puuttuu yhä, ja valmistumisen jälkeisiä opintoja käsittelevä osa rajoittuu vain ammatillisiin näkökulmiin. On kuitenkin tärkeä panna merkille, että näissä projekteissa korostetaan välttämättömyyttä rahoittaa kansallisesti tai alueellisesti merkittäviä jatkokoulutusprojekteja myös valtion tai alueiden budjeteista. Niille yrityksille, jotka rahoittavat akkreditoitujen koulutuslaitosten opetuspalveluita, suunnitellaan verohelpotuksia.

Tällaisten toimenpiteiden liittäminen projektien osaksi ei kuitenkaan poista tarvetta erilliseen lakiin tai yleisen lain osaksi liitettävään lakiin, joka määrittelisiaikuiskasvatuksenyhteiskunnallisen asemanja takaisi sille valtiontuen.
5 Aikuiskasvatuksessa on alettu tuntea suurta tarvetta erityisvalmiuksia omaavaan aikuispedagogiikkaan. Andragogisen koulutuksen puute johtaa siihen, että aikuiskasvattajien dominoiva periaate on "tunne asiasi ja esitä se selkeästi". Mitä enemmän opettaja on oman alansa erikoisasiantuntija, sen neutraalimmin hän asennoituu psykologis-pedagogiseen kirjallisuuteen. Kuitenkaan tehtäessä työtä aikuisten kanssa ei voida luottaa menestykseen, ellei aikuisille anneta mahdollisuutta tiedon omakohtaiseen konstruointiin, jotta uusi opittu tieto olisi hänelle arvokas ja tulisi todella löydetyksi. Voidaan tehdä loppupäätelmä, että aikuiskasvatuksen osaajien kouluttaminen ja pedagogien kyvyn kohottaminen työskennelläaikuisten, vaikkapa vanhempien kanssa, on yksi keskeisimmistätehtävistä.

Edellä kuvattujen ongelmien ratkaiseminen on mahdollista vain valtion, yhteiskunnan ja kansalaisten yhteistyönä sekä ulkomaisten järjestöjen (esimerkiksi Saksan kansanopistoliiton kansainvälisen yhteistyön instituutin DVV / IIZ) aktiivisen tuen avulla. Ne on kutsuttu tekemään aikuiskasvatus yhdeksi tärkeimmistä tekijöistä Venäjän talouden kehittämisessä ja kansalaisyhteiskunnan synnyttämisessä.

\section{Viitteet}

1 Esimerkiksi kaupallisten kasvatuskeskusten ammatillisen valmentamisen asiantutkijatarkastus osoitti, että 80 prosenttioa liikealan diplomeista ei taannut vaadittavaa laatua.

2 Katso S.G. Veršlovskij: Obšee obrazovanie vzroslyh: stimuly i motivy. -Moskova, 1987 ["Yleinen aikuiskasvatus: virikkeet ja motiivit"]; L.N. Lesohina: K obšestvu obrazovannyh lûdei (teoriâ i praktika obrazovaniâ vzroslyh) - Pietari, 1998 ["Kohti sivistyneiden ihmisten yhteiskuntaa (aikuiskasvatuksen teoria ja käytäntö)"]; Obrazovanie vzroslyh: realnosti, problemy, prognoz ( toim. S.G. Veršovskij) - Pietari, 1998 ["Aikuiskasvatus: käytännön seikkoja, ongelmia ja ennuste"]

3 Tarkemmin invalidien kasvatustoiminnan erikoisuuksia kuvataan kirjassa "Raboèaja kniga andragoga" (toim. S.G. Veršlovskij) -Pietari, 1998, sivut 96-108

4 Katso: V.V. Frol'kis: Starenie i uvelièenie prodolzhitel'nosti zhisni - Leningrad 1988; K. Visnevska-Roskovska: Novaâ zhisn' posle šestidesâti Moskova 1989; V.V. Boèarov: Antropologiâ vozrasta - Pietari 2000.

5 Sankt-Peterburgskie vedomosti, 30 lokakuuta 1996

Professori Veršlovskin esittely ja yhteystiedot, s. 80 Käännös venäjästä: AKSELI KAJANTO 